\title{
Verbondenheid met anderen
}

\section{Grondlegger van de contextuele therapie Iván Böszörményi-Nagy overleden}

\author{
Wilma van Klaveren
}

Op 28 januari 2007 overleed Prof. dr. Iván BöszörményiNagy op 86-jarige leeftijd. Iván Nagy (uitgesproken als 'nodzj'), hoogleraar Psychiatrie en grondlegger van de contextuele familietherapie, werd geboren op 19 mei 1920 te Boedapest waar hij geneeskunde studeerde en psychiater werd. In 1950 verliet hij zijn geboorteland Hongarije en daarmee het onrecht en de ravage die Hitler en Stalin achterlieten. Hij emigreerde naar de VS waar hij vanaf 1957 leiding gaf aan de therapeutische afdeling van het Eastern Pennsylvenia Psychiatric Institute. Tijdens zijn werk ontdekte hij dat de behandeling van cliënten beter aansloeg als hij daar familieleden bij betrok. Nagy was altijd op zoek naar hoop en optimisme, geschokt als hij was door hoe bepaalde groepen in de samenleving, van psychotici tot daklozen, vanuit pessimisme werden benaderd en zelfs werden opgegeven. De relationele verbondenheid met anderen bleek hoop te geven, en bij te dragen aan het vergroten van rechtvaardigheid. Het werd de start van een veelomvattend denken over het immense belang van de relationele context van ieder mens. Mensen zijn onlosmakelijk verbonden met voor hen belangrijke anderen.

Samen met Salvador Minuchin, Virginia Satir en anderen leverde Nagy een belangrijke bijdrage aan de ontwikkeling van de gezins- en familietherapie. Hij werd in zijn denken sterk beïnvloed door onder meer het werk van de Duits-Joodse filosoof Martin Buber voor wie een mens slechts mens wordt in relatie tot de ander. Vanuit dat denken en gedreven door een zoeken naar rechtvaardigheid, kwam hij tot de toevoeging van een extra dimensie in de hulpverlening. Niet alleen de feiten, niet alleen de psychologie, niet alleen de systeemwetten tellen. Onderlinge verbondenheid en trouw, loyaliteiten en een balans in geven en ontvangen bleken minstens even belangrijk. Uit die meer ethische dimensie bleek onrecht erkend te kunnen worden en hoop aangewakkerd! Want dat is waar het bij hulpverlening voor Nagy uiteindelijk om te doen was: dat mensen nieuwe hoop en vrijheid zouden verwerven, vanuit verbondenheid met anderen.

In het maatschappelijk werk is de invloed van Nagy groot. Via Ammy van Heusden werd het denken van Nagy in het Nederlands taalgebied bekend. Vanaf de tachtiger jaren verzorgde Nagy regelmatig workshops in Europa. In de jaren negentig gaf hij Masterclasses Contextuele Therapie in Amsterdam. Op vrijwel alle hbo-opleidingen MWD zijn contextuele modules opgenomen in het studieprogramma. Honderden maatschappelijk werkers, leerlingbegeleiders, pastores en therapeuten zijn of worden contextueel geschoold via de inmiddels diverse post-hbo opleidingstrajecten in België en Nederland. Een eigen vakvereniging, de Vereniging van Contextueel Werkers (VCW) spant zich in om het contextuele denken en werken te stimuleren. Het werk van Nagy maakt een einde aan pessimisme en hopeloosheid, aan parent blaming en aan eenzaamheid. En wat is het goed om als hulpverlener aan te mogen sluiten bij het verlangen van alle mensen om van betekenis te zijn, om er toe te doen, om op een betrouwbare manier verbonden te zijn met de ander. Ik hoor het hem nog zeggen in een van de laatste colleges die ik bij hem volgde: 'Vergeet toch nooit op zoek te gaan naar dat wat mensen geven. Dat is wat mensen ten diepste het gevoel geeft van betekenis te zijn en er toe te doen. Remember: it's all in the giving.' Iván Böszörményi- Nagy gaf ons veel om dankbaar voor te zijn. 